\title{
Vertical migration behavior and larval transport in brachyuran crabs
}

\author{
Lance P. Garrison* \\ School of Marine Science, Virginia Institute of Marine Science, The College of William and Mary, Gloucester Point, \\ Virginia 23062, USA
}

\begin{abstract}
I documented the patterns of vertical distribution and abundance of zoeae from 3 families of brachyuran crabs in the York River, a sub-estuary in southern Chesapeake Bay (USA). The family groups included species from Ocypodidae, Pinnotheridae, and Panopeidae. I assessed the effects of light and tidal current stage on the abundance and vertical distribution of zoeae using analysis of variance (ANOVA) and logistic regression. Clear behavioral patterns were evident in the logistic regression. Ocypodid larvae exhibited tidally timed behavior with larvae nearest the surface during ebb tides. Pinnotherid larval behaviors were correlated with both light and tidal current phase. Larvae were nearest the surface at night and during ebb tides. Panopeid larvae were near the bottom during early flood tides, near mid-depths during late flood and early ebb tides, and nearest the surface during late ebb tides. These behavioral patterns should result in horizontal distributions that are consistent with those observed in previous studies. The ANOVA reflected similar results; however, high variability between replicates weakened the significance of these patterns. The different analyses reflect processes on different spatial and temporal scales. The samples were replicated on short time scales (5 to 10 min). The logistic regression, a categorical analysis, largely ignores the variation between replicates and reflects average behaviors on the scale of several tidal cycles. In contrast, the ANOVA is highly sensitive to the variation between replicates and reflects patterns on scales of minutes. This high variation reflects turbulent vertical mixing and fine-scale horizontal patchiness in larval distribution. Small-scale physical processes that redistribute larvae both vertically and horizontally may have a strong influence on the variability in dispersal and recruitment success.
\end{abstract}

KEY WORDS: Vertical migration $\cdot$ Zoeae $\cdot$ Larval behavior $\cdot$ Larval transport

\section{INTRODUCTION}

The non-tidal residual flow in partially mixed estuaries results in downstream transport and flushing of passive particles (Boehlert \& Mundy 1988, Queiroga et al. 1997). The planktonic larvae of marine invertebrates are unable to directly overcome these horizontal flows (Young 1995); however, larval vertical migration behavior can promote selective transport by tidal currents and uncouple larval dispersal from residual flow (Boehlert \& Mundy 1988, Hill 1995, Queiroga et al. 1997). Crustacean larvae typically employ tidally timed vertical migration behaviors to promote directed

\footnotetext{
- Address for correspondence: National Marine Fisheries Service, Northeast Fisheries Science Center, 166 Water Street, Woods Hole, Massachusetts 02543, USA.

E-mail: lgarriso@whsun1.wh.whoi.edu
}

transport. Both re-invading post-larvae that are carried upstream by flood tides (e.g. Callinectes sapidus, Olmi 1994) and zoeae that move downstream during ebbing tides (e.g. Carcinus maenas, Zeng \& Naylor 1996a, Queiroga et al. 1997) utilize selective tidal stream transport.

The brachyuran crabs in estuarine species exhibit a range of larval dispersal strategies. Typically, these patterns range from strong retention in tidal creeks (e.g. Rhithropanopeus harrissi, Cronin \& Forward 1986) to rapid export of larvae to the continental shelf (e.g. Callinectes sapidus, Epifanio 1988a). Broad patterns in the horizontal distribution of crab zoeae are extremely well documented (Sandifer 1972, Dittel \& Epifanio 1982, Epifanio 1984, Brookins \& Epifanio 1985). The important species occurring within estuarine systems are broadly categorized either as retained or exported based upon zoeal (e.g. Sandifer 1972, Goy 
1976, Dittel \& Epifanio 1982) or megalopal (Johnson 1982) distributions. In addition, broad patterns in the vertical migration behaviors of retained versus exported species are well characterized (Brookins \& Epifanio 1985, Epifanio 1988a,b, McConaugha 1988). In retained zoeae or re-invading post-larvae, larvae are generally nearest the surface during flood tides and near the bottom during ebb tides (Cronin \& Forward 1986, McConaugha 1988, Olmi 1994), resulting in strong upstream transport. In exported species, larvae are thought to either maintain position near the surface at all times (Epifanio 1988a) or selectively remain near the surface during ebb tides, promoting rapid downstream transport (Zeng \& Naylor 1996b, Queiroga et al. 1997).

Active vertical migration by crustacean larvae and post-larvae is accomplished by swimming against weak vertical flows. Larval swimming speeds typically range from 3 to $12 \mathrm{~mm} \mathrm{~s}^{-1}$ and increase with larval age (Sulkin 1984). Zoeal swimming behaviors are affected by a diverse suite of environmental parameters in laboratory studies, including light, temperature, salinity, and pressure (Sulkin 1984, Forward 1989). Larval behaviors are also associated with endogenous activity cycles that are triggered during the embryo stage and are timed to natural tidal cycles (Cronin \& Forward 1986, Zeng \& Naylor 1996b). Vertical migration behaviors may be overcome through physical mixing in the water column. Vertical mixing may be strong enough to overcome behaviors during periods of strong winds, freshwater input, or in areas of high flow such as tidal inlets (Smith \& Stoner 1993). Strong vertical mixing reduces the ability of larvae to actively regulate depth.

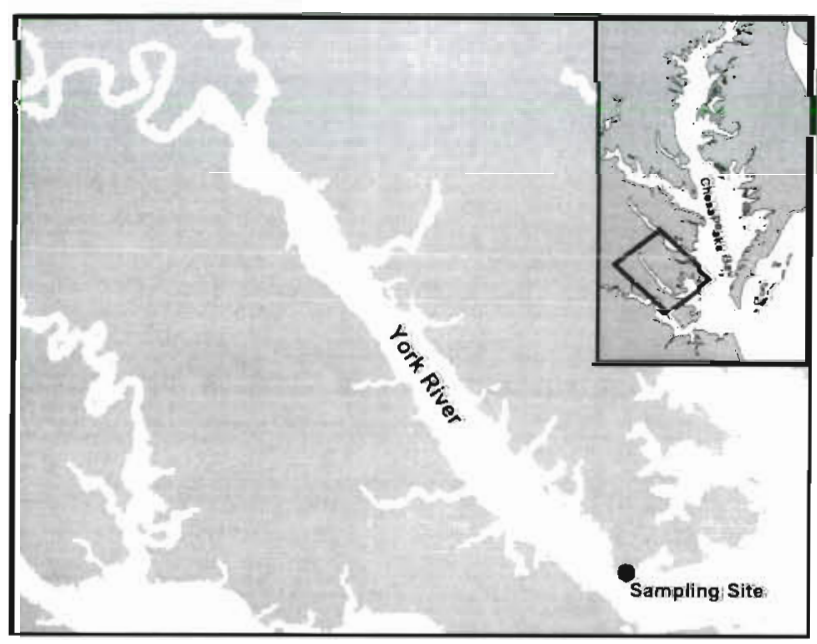

Fig. 1 Study site. Plankton samples were collected from a fixed station near the mouth of the York River in Lower Chesapeake Bay, USA
While broad patterns of vertical distribution have been well documented, relatively few studies have conducted intensive sampling on short time scales to directly measure vertical distribution patterns in the field (e.g. Brookins \& Epifanio 1985, Cronin \& Forward 1986, Epifanio et al. 1988, Queiroga et al. 1997). While these studies sampled on hourly time scales, they were replicated over several tidal cycles and therefore do not document small-scale variation on scales of minutes. This short-term variation is related to small-scale physical processes, including turbulence, and may strongly influence the dispersal and recruitment success of planktonic larvae. The goal of this study was to characterize the vertical migration behaviors and patterns of abundance in the zoeae of 3 families of brachyuran crabs with a range of larval dispersal strategies: Ocypodidae (Uca spp.), Pinnotheridae, and Panopeidae. Particular attention was paid to the influence of behavioral processes associated with tidal and light cycles. Sampling was replicated on short time scales ( 5 to $10 \mathrm{~min}$ ), thereby including the influence of. small-scale physical processes within the analyses.

\section{MATERIALS AND METHODS}

Study site. Plankton samples were collected from a fixed location at the Virginia Institute of Marine Science Ferry Pier in the lower York River, Chesapeake Bay, USA (Fig. 1). This location is characterized by a salinity range of 18 to 20 psu and temperatures from 24 to $28^{\circ} \mathrm{C}$ during summer months. The York River is a typical coastal flood plain estuary characterized by a deep central channel with expansive shallow subtidal mud and sand flats. Water depth at the study site is approximately $2.5 \mathrm{~m}$ at low tide, with a tidal range of approximately $1.5 \mathrm{~m}$ on spring tides. The system is dominated by the M2 (period = $12.4 \mathrm{~h}$ ) and S2 (period $=24 \mathrm{~h}$ ) tidal constituents. There is a semi-diurnal tidal cycle and a spring-neap tidal amplitude cycle with a period of 14 d (Huzzey 1986). Samples were collected on 4 dates in June and July, 1995, during spring tides associated with the full (13 June 1995 and 12 July 1995) and new (27 June 1995 and 27 July 1995) moons.

Target families. At least 8 species of zoea representing 3 families (Ocypodidae, Pinnotheridae, and Panopeidae) were included in the study (see Table 1). The Ocypodidae were represented by up to 3 species of the genus Uca which occur locally as adults but cannot be distinguished in the plankton: $U$. minax, $U$. pugnax, and U. pugilator (Williams 1984) These semi-terrestrial crabs inhabit salt marshes throughout estuarine systems (Sandifer 1972, Williams 1984). UCa spp. zoeae are hatched in salt marshes and are rapidly transported to the bay mouth and nearshore continental 
shelf where they complete larval development (Sandifer 1972, Goy 1976, Johnson 1982). Uca spp. larvae are considered an exported species, and post-larvae were nearly evenly distributed between the bay mouth and nearshore continental shelf in Chesapeake Bay (Johnson 1982). These larvae have short rostral and dorsal spines (Fig 2) and are more susceptible to predation by larval fish than other zoeae (Morgan 1986).

Three species of Pinnotheridae were included in this study: Pinnotheres maculatus, Pinnixia chaetopterana, and Pinnixia sayana. These are subtidal commensal crabs with adult distributions throughout estuaries (Williams 1984). All 5 zoeal stages were abundant near the mouth of the York River and in the lower portions of Chesapeake Bay (Sandifer 1972, Goy 1976). Postlarvae were present on the continental shelf (Johnson 1982). Pinnotherid zoeae generally have longer dorsal, rostral, and lateral spines than Uca spp. (Fig. 2).

The 4 species of Panopeidae (formerly Xanthidae; Martin \& Abele 1986) included in this study are subtidal mud crabs that inhabit the lower portions of estuaries (Williams 1984): Dyspanopeus sayi, Panopeus herbstii, Hexapanopeus angustifrons, and Eurypanopeus depressus. Larvae were abundant in lower estuaries and near bay mouths (Sandifer 1972, Goy 1976), and post-larvae occurred in the lower and middle Chesapeake Bay (Johnson 1982). The larval and post-larval distributions of this family indicate that they are retained in the lower estuary. Panopeid larvae are characterized by long dorsal and rostral spines (Fig. 2) that serve as effective defenses against larval fish predators (Morgan 1986).

All analyses in the present study compared data among these 3 families. Due to small sample sizes, it was impossible to directly evaluate vertical migration behaviors by species. Family was selected as an appropriate taxonomic grouping due to similarities in life history and larval dispersal patterns. The species included in each group have similar adult habitats (Williams 1984). Broad-scale horizontal and vertical larval distributions are similar among the species within each group (Sandifer 1972, Goy 1976), and postlarval distributions are similar among species (Johnson 1982). Life histories, the number of zoeal instars, and adult habitats are generally consistent at the family level in the brachyuran crabs (Hines 1986).

Sample collection. Plankton samples were collected using centrifugal water pumps fitted with variable length intake pipes constructed from 2 inch (ca $5 \mathrm{~cm}$ ) diameter PVC pipe. Volume flow rates were determined by measuring the time required to fill a known volume and ranged from 0.452 to $0.546 \mathrm{~m}^{3} \mathrm{~min}^{-1}$. Replicate samples were collected from each of 3 depths: surface $(0.5 \mathrm{~m}$ below water surface), mid-depth ( $1 / 2$ total water column depth), and bottom $(0.5 \mathrm{~m}$ above

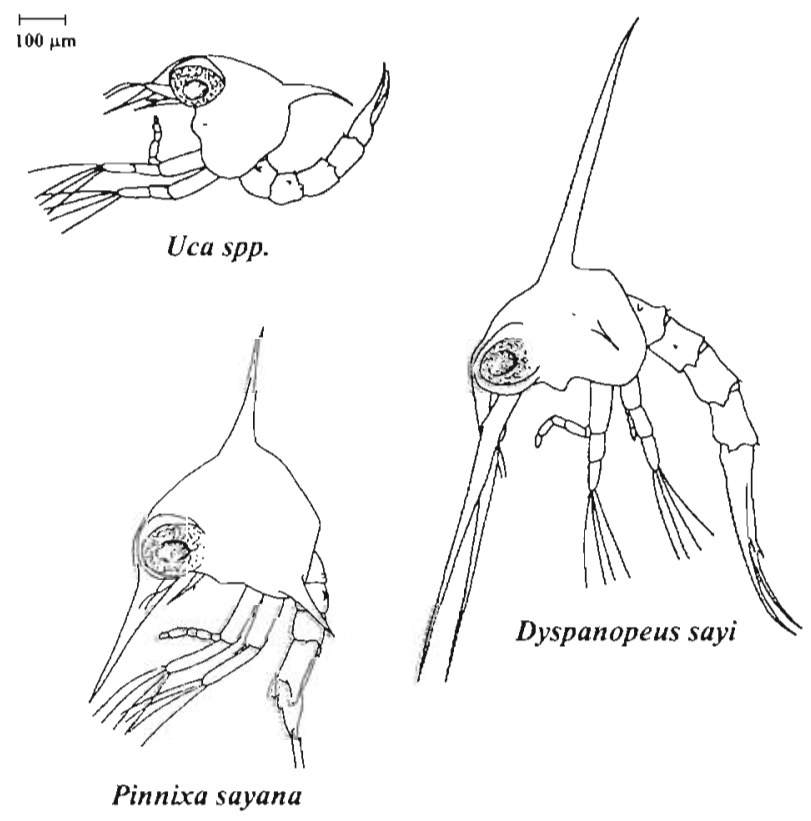

Fig. 2. Typical first stage zoeae from each of the 3 family groups used in this study (Sandifer 1972)

the substrate). The absolute depth of the mid-depth sample was adjusted to reflect changes in water column height associated with tidal phase. Individual replicates consisted of pumping periods of $5 \mathrm{~min}$, with water volume sampled per replicate ranging from 2.26 to $2.73 \mathrm{~m}^{3}$. Three replicates per depth/time combination were taken in June samples and 4 replicates were taken during July samples (total $n=369$ ).

Samples were taken every $3 \mathrm{~h}$ beginning at $00: 00 \mathrm{~h}$ EDT (Eastern Daylight Time) on each date. This sampling frequency was chosen to allow for 2 sample collections during each tidal current phase (period $=6 \mathrm{~h}$ ). Collection occurred during the hour starting at each sampling time. Replicate 5 min samples were randomly allocated across sampling period, depth, location (20 locations at $1 \mathrm{~m}$ intervals along the pier), and pump (3 pumps).

Pump outflow was filtered through a $202 \mu \mathrm{m}$ mesh nitex plankton net. Samples were fixed in $5 \%$ formalin and transferred to $70 \%$ EtOH. Sub-samples of $1 / 2$ to $1 / 16$ total volume were taken, and all zoeae were identified to species (Sandifer 1972).

Statistical analyses-larval concentration. Larval concentration (larvae $\mathrm{m}^{-3}$ ) was the response variable in an analysis of variance model (ANOVA) for each taxonomic group. Raw data failed to meet the assumptions of normality (Shapiro-Wilks, $\mathrm{p}<0.01$ ) and homogeneity of variance (Bartlett's test, $p<0.001$ ). All data were logtransformed $\left(\ln \left[\right.\right.$ zoeae $\left.\left.\mathrm{m}^{-3}+1\right]\right)$ to satisfy the assumptions of the analyses (Underwood 1981). Date was treated as a random blocked factor (Newman et al. 1997) to account 
for differences in mean larval concentration between dates. Three fixed factors were included in the model: depth of sample, light stage, and tidal current phase. Since samples were collected at $3 \mathrm{~h}$ intervals, tidal current phase was separated into 4 levels reflecting the direction of flow: early flood, late flood, early ebb and late ebb (tidal phases 1 to 4 respectively). The tidal current phase at the time of sample collection was determined both by direct observation of the current direction and magnitude and by comparison to predicted tidal currents based on NOAA tide tables.

Samples were collected during the full and new moons associated with spring tides to ensure high densities of first stage zoeae. Hatching during spring tides is a consistent feature among a variety of estuarine crabs (Morgan \& Christy 1995). However, due to the phasing between the light and tidal cycles, nocturnal early flood tides did not occur on the sampling dates. As a result, the 3 crossed factors (tidal phase, light and depth) were not orthogonal in the experimental design. While the missing cells (nocturnal early flood tides) limit the hypotheses that can be explicitly tested in the ANOVA, they do not preclude the application of this method and interpretation of the data. In nonorthogonal designs it is necessary to explicitly structure the hypotheses tested in the general linear model to insure meaningful comparisons (Milliken \& Johnson 1984). The ANOVA was conducted utilizing the procedures recommended by Milliken \& Johnson (1984).

Specifically, the 3 crossed factors were jointly tested using partial hypotheses. The tidal phase and depth effects and their interaction were tested separately for each light stage. Only late flood (phase 2), early ebb (phase 3), and late ebb (phase 4) tidal phases could be included in the models for night samples, while all 4 tidal phases (including early flood, phase 1) were included for day samples. The light effect and the 2 - and 3 -way interactions with light could only be tested for tidal phases 2 to 4 . While the model is not a complete design, it is still capable of testing meaningful hypotheses regarding the effects of tidal and light stage on both the abundance and vertical distribution of crab zoeae.

The Student-Newman-Keuls (SNK) multipie comparisons test was used to conduct pairwise comparisons between factor levels in interaction effects and main effects with $>2$ levels when $p$-values were $<0,10$ (Underwood 1981). Data are presented as back-transformed means and $95 \%$ confictence intervals (Sokal \& Rohlf 1981).

Statistical analyses-logistic regression. Vertical distribution patterns were analyzed with logistic regression models. The logistic model is less sensitive than the ANOVA to the high amount of variance between replicates observed in the data. The response variable was depth. The polytomous model using all 3 depths did not meet the proportional odds assumption $(\mathrm{p}<0.001)$, therefore response levels were collapsed into a binomial response (Hosmer \& Lemeshow 1989). The model evaluated the probability of larvae being in the surface sample versus the mid-depth and bottom samples. There was no qualitative difference between models using this response and the alternative testing surface and mid-depth versus bottom samples. As a binary model, the probability of larvae being in the bottom and mid-depth samples is inversely related to the probability of their being in the surface sample. The explanatory variables included date (4 levels), light stage (2 levels), current phase (ebb or flood), and period in current phase (early or late). Explanatory variables were fitted using a step-wise logistic regression (Hosmer \& Lemeshow 1989).

\section{RESULTS}

\section{Species composition and abundance}

Zoeae from at least 8 species were included in the family groups used for analysis. Most larvae were in the first instar, and there was little apparent change in species composition through time. The Uca spp. (Family Ocypodidae) larvae were by far the most abundant group, and they represented $76 \%$ of all zoeae (Table 1). More Stage II and Stage III larvae were collected in July samples; however, the majority of larvae were in the first instar (Table 1). Very few (<1.0) Stage IV larvae and no Stage $V$ larvae were collected. The Pinnotheridae were the least abundant taxa $(4.8 \%$, Table 1). Fewer than 20 larvae later than Stage I were collected. Pinnixia chaetopterana dominated the Pinnotheridae $(75.2 \%)$. A total of $19.2 \%$ of collected larvae were from Panopeidae (Table 1), and Hexapanopeus angustifrons was the most abundant panopeid species (45.1\%, Table 1)

In all 3 families, there were highly significant differences in larval concentration between sampling dates (Tables 2 to 4, Fig. 3A-C). Larval concentrations for Uca spp. were significantly higher in July, and the highest concentrations occurred during the July full moon. For Pinnotheridae, the highest larval concentra. tion occurred during the late June and early July sampling periods (Fig. 3B). The highest larval concentrations for Panopeidae occurred during the June new moon, and there were no significant differences among the other dates (Fig. 3C).

\section{Analysis of variance - larval concentration}

In Uca spp. larvae, there was a significant effect of tidal phase on larval concentration during both day 
and night samples (Table 2). The highest densities consistently occurred during early tidal phases (i.e. early ebbs and early floods, Fig. 4A, B). Larval concentration was significantly higher during early ebb tides in night samples (Fig, 4A). A nearly significant $(p=0.0609)$ phase $x$ depth interaction effect for day samples suggests a weak effect of tidal current phase on larval depth distribution (Table 2). During flood tides, significantly higher densities occurred near the bottom, while during ebb tides larvae were more evenly distributed in the water column or highest densities occurred near the surface (Fig. 4B).

In pinnotherid zoeae, both light and tidal current phase had a significant effect on larval depth distribution and concentration. The 3-way interaction between phase, light, and depth was highly significant (Table 3). There were significant differences in larval depth distribution between tidal current phases, and these patterns differed between light stages. During night sampling, the highest concentration of larvae occurred near mid-depths during the late flood tidal phase. Larvae were more evenly distributed in the water column during early ebbs, and they were more abundant near the surface during late ebb tides (Fig. 5A). During day sampling, the highest densities occurred near the bottom during flood tides, and larvae were most abundant in the mid-depth sample during early ebb. Larval densities were extremely low during daytime, late ebb tides (Fig. 5B).

In panopeid zoeae, there was no clear indication of tidal or light driven behaviors. There was a nearly significant $(p=0.056)$ phase $\times$ depth effect for night samples and a highly significant tidal phase effect for day samples (Table 4). During late floods at night, larvae were more abundant near the bottom, while larvae were more abundant near the surface during late ebbs (Fig. 6A). During day sampling, larvae were more abundant during the late flood and early ebb tidal current phases (Fig. 6B). While the data indicate some tidal patterns in larval concentration and vertical distribution, no clear behavioral pattern was apparent.

\section{Logistic regression - vertical distribution}

In Uca spp., the vertical distribution of larvae was correlated solely with tidal current phase. The logistic model including current phase and replicate was highly significant (Table 5) and provided an improved
A) Uca spp.

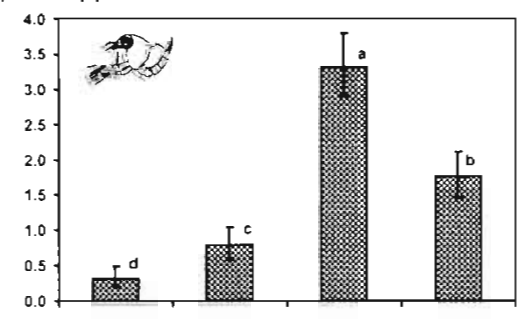

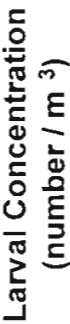

B) Pinnotheridae

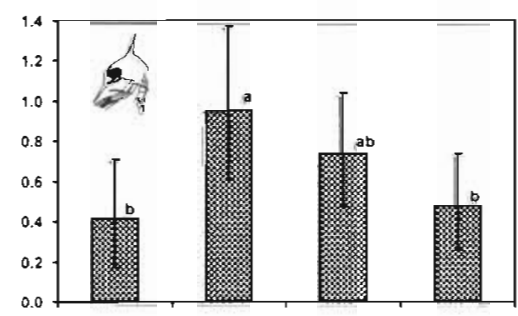

C) Panopeidae

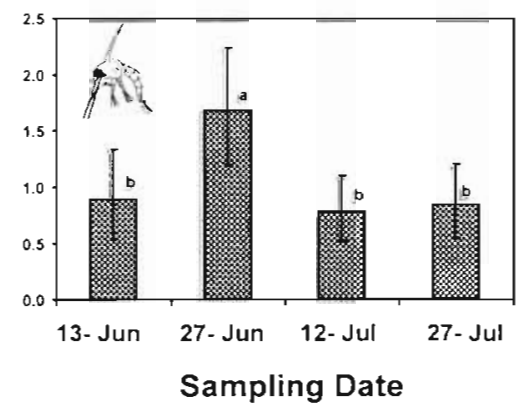

Fig. 3. Back-transformed mean concentration of zoeae by date. Bars with different letters differ significantly (StudentNewman-Keuls multiple comparisons test). Open circles: full moon; closed circles: new moon. Error bars are back-transformed $95 \%$ confidence intervals 


\section{A. Night Samples}

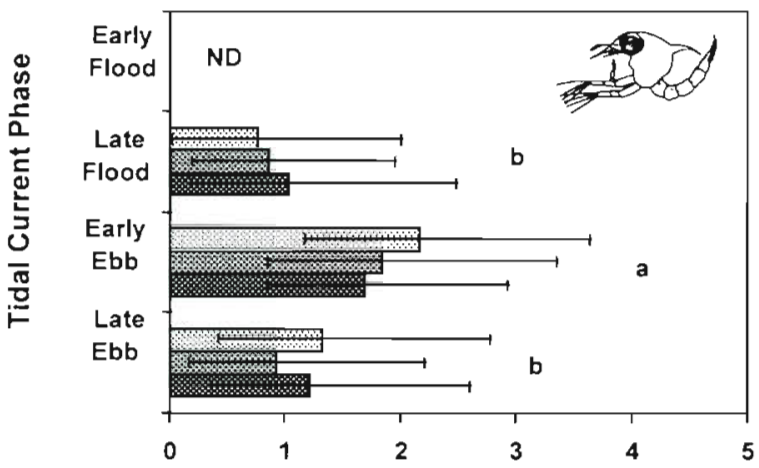

B. Day Samples

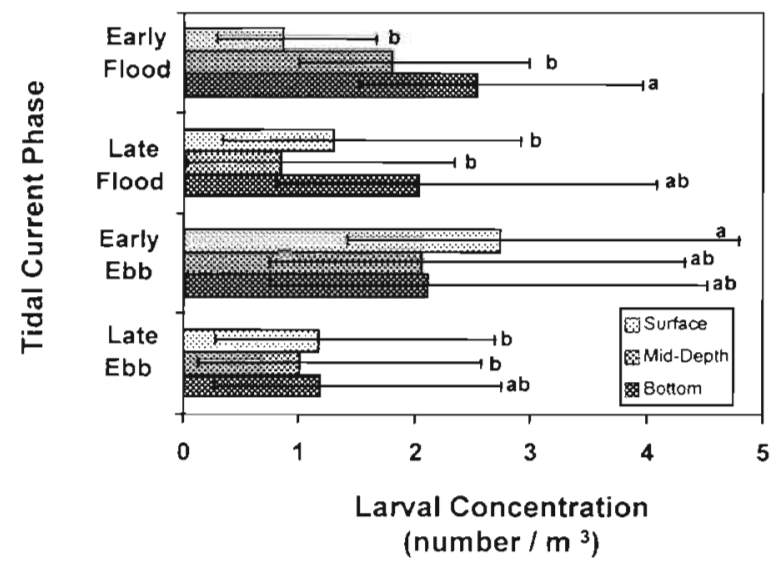

Fig. 4. Uca spp. Concentration of zoeae by depth and tidal phase. Data presented as back-transformed mean larval concentration for each depth. Bars with different letters are significantly different (Student-Newman-Keuls multiple comparisons test). Error bars represent $95 \%$ confidence intervals. ND: no data

fit over the mutual independence model. Replicate was included in the model to increase degrees of freedom and avoid saturation. Tidal current phase was a significant predictor of the proportion of larvae in the surface sample (Table 5). The odds ratio indicates that larvae were nearly twice as likely to be in the surface sample during ebb tides than flood tides (Fig. 7, Table 5).

In Pinnotheridae, a logistic model including date, current, and light best predicted the vertical distribution of zoeae. The overall model was highly significant and explained a significant amount of the variation (Table 5). Date was a significant factor and had a negative parameter value. The probability of larvae being in the surface sample declined over time through the 4 sampling dates (Table 5, Fig. 8A-D). Tidal current phase was a highly significant predictor of vertical position. Larvae were nearly 4 times more likely to be in the surface on ebb than flood tides (Table 5). Light
Table 2. Uca spp. ANOVA. Date was included as a random blocked factor. The overall model was highly significant $(F=$ $6.229, \mathrm{df}=31,318, \mathrm{p}<0.0001) . \cdot 0.05<\mathrm{p}<0.1, \cdots \mathrm{p}<0.05$, $\cdots p<0.01, \cdots p<0.001$

\begin{tabular}{|c|c|c|c|c|}
\hline Source & $\mathrm{df}$ & SS & MS & $F$-ratio \\
\hline Date & 3 & 12.864 & 4.288 & $49.459 \cdots$ \\
\hline \multicolumn{5}{|c|}{ Night samples } \\
\hline Phase (P) & 2 & 0.668 & 0.334 & $3.852 \cdots$ \\
\hline Depth (Z) & 2 & 0.032 & 0.016 & 0.187 \\
\hline$P \times Z$ & 4 & 0.164 & 0.082 & 0.473 \\
\hline \multicolumn{5}{|l|}{ Day samples } \\
\hline Phase (P) & 3 & 0.816 & 0.272 & $3.138^{\circ}$ \\
\hline Depth (Z) & 2 & 0.259 & 0.130 & 1.496 \\
\hline$P \times Z$ & 6 & 1.026 & 0.171 & $1.974^{\circ}$ \\
\hline \multicolumn{5}{|l|}{ Stages 2-4 } \\
\hline Light (L) & 1 & 0.253 & 0.253 & $2.918^{\circ}$ \\
\hline$L \times Z$ & 2 & 0.036 & 0.018 & 0.208 \\
\hline$P \times L$ & 2 & 0.127 & 0.064 & 0.730 \\
\hline $\mathrm{P} \times \mathrm{L} \times \mathrm{Z}$ & 4 & 0.093 & 0.023 & 0.268 \\
\hline Error & 318 & 27.566 & 0.0867 & \\
\hline
\end{tabular}

Table 3. ANOVA for Pinnotheridae. Date was included as a random blocked factor. The overall model was highly significant $(F=4.176, \mathrm{df}=31,318, \mathrm{p}<0.0001) \cdot 0.05<\mathrm{p}<0.1$, $\cdots p<0.05, \cdots p<0.01, \cdots p<0.001$

\begin{tabular}{|c|c|c|c|c|}
\hline Source & df & SS & MS & $F$-ratio \\
\hline Date & 3 & 5.340 & 1.780 & $4.358^{\cdots} \cdot$ \\
\hline \multicolumn{5}{|c|}{ Night samples } \\
\hline Phase (P) & 2 & 1.120 & 0.560 & 1.371 \\
\hline Depth (Z) & 2 & 0.142 & 0.071 & 0.174 \\
\hline$P \times Z$ & 4 & 5.689 & 1.422 & $3.482 \cdots$ \\
\hline \multicolumn{5}{|l|}{ Day samples } \\
\hline Phase $(\mathrm{P})$ & 3 & 14.929 & 4.976 & $12.184 \cdots$ \\
\hline $\operatorname{Depth}(\mathrm{Z})$ & 2 & 2.131 & 1.066 & $2.610^{\circ}$ \\
\hline$P \times Z$ & 6 & 5.873 & 0.979 & $2.397^{*}$ \\
\hline \multicolumn{5}{|l|}{ Stages $2-4$} \\
\hline Light (L) & 1 & 0.816 & 0.816 & 1.998 \\
\hline$L \times Z$ & 2 & 0.627 & 0.314 & 0.767 \\
\hline$P \times L$ & 2 & 9.311 & 4.655 & $11.399 \cdots$ \\
\hline $\mathrm{P} \times \mathrm{L} \times \mathrm{Z}$ & 4 & 6.905 & 1.726 & $4.226^{\cdots}$ \\
\hline Error & 318 & 129.885 & 0.408 & \\
\hline
\end{tabular}

was also significant with a negative parameter value Larvae were nearly twice as likely to be near the surface at night (Table 5). The logistic regression models showed results similar to the 3-way interaction effect in the analysis of variance. Pinnotherid behaviors were associated with both current and light cycles

In panopeid zoeae, vertical distribution was correlated with tidal current phase and the period in the current phase. The logistic model including current and period was highly significant and fit the data extremely well (Table 5). Both factors were positively 


\section{A. Night Samples}

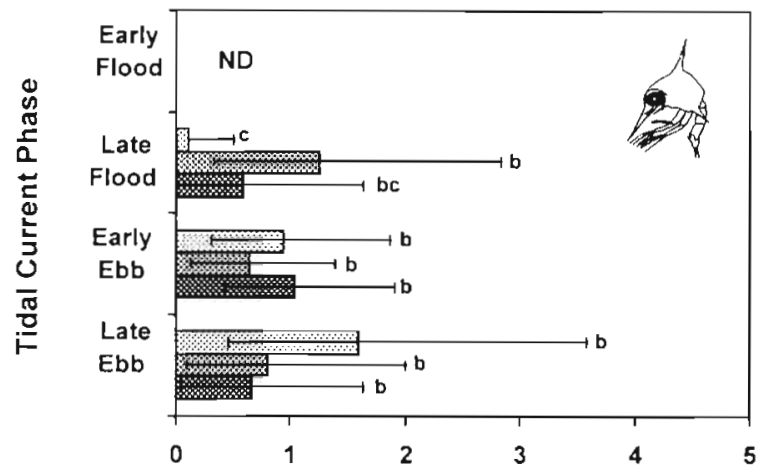

B. Day Samples

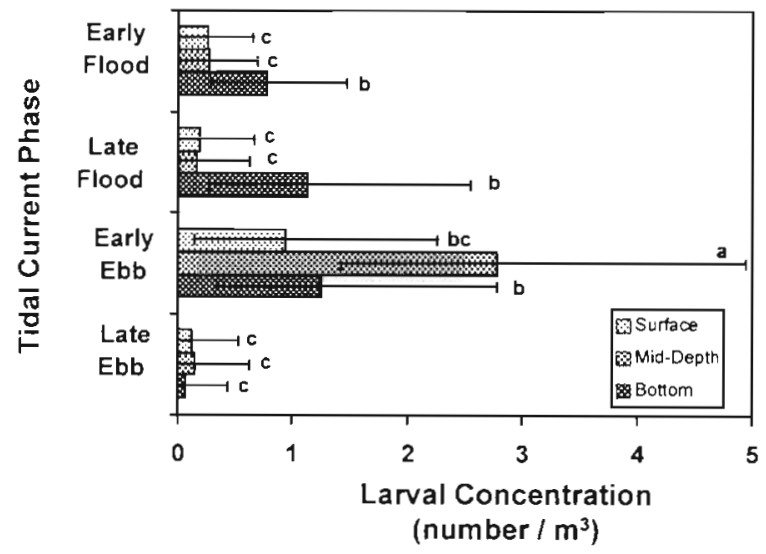

Fig. 5. Concentration of pinnotherid larvae by depth and tidal phase. Data presented as back-transformed mean larval concentration for each depth. Bars with different letters are significantly different (Student-Newman-Keuls multiple comparisons test). Error bars represent $95 \%$ confidence intervals. ND: no data

Table 4. ANOVA for Panopeidae. Date was included as a random blocked factor. The overall model was significant $(F=$ 1.708, df $=31,318, \mathrm{p}=0.0134) .{ }^{*} 0.05<\mathrm{p}<0.1,{ }^{*} \mathrm{p}<0.05$, $\cdots p<0.01, \cdots p<0.001$

\begin{tabular}{|c|c|c|c|c|}
\hline Source & df & SS & MS & $F$-ratio \\
\hline Date & 3 & 1.751 & 0.584 & $5.822^{\cdots} \cdots$ \\
\hline \multicolumn{5}{|c|}{ Night samples } \\
\hline Phase $(\mathrm{P})$ & 2 & 0.214 & 0.107 & 1.068 \\
\hline Depth (Z) & 2 & 0.095 & 0.047 & 0.472 \\
\hline$P \times Z$ & 4 & 0.931 & 0.233 & $2.322^{\circ}$ \\
\hline \multicolumn{5}{|c|}{ Day samples } \\
\hline Phase $(\mathrm{P})$ & 3 & 1.369 & 0.456 & $4.552^{\cdots}$ \\
\hline Depth(Z) & 2 & 0.210 & 0.105 & 1.048 \\
\hline$P \times Z$ & 6 & 0.303 & 0.050 & 0.503 \\
\hline \multicolumn{5}{|l|}{ Stages $2-4$} \\
\hline Light(L) & 1 & 0.041 & 0.041 & 0.407 \\
\hline$L \times Z$ & 2 & 0.116 & 0.058 & 0.578 \\
\hline $\mathrm{P} \times \mathrm{L}$ & 2 & 0.469 & 0.235 & $2.341^{\circ}$ \\
\hline$P \times L \times Z$ & 4 & 0.255 & 0.064 & 0.639 \\
\hline Error & 318 & 31.876 & 0.100 & \\
\hline
\end{tabular}

A. Night Samples

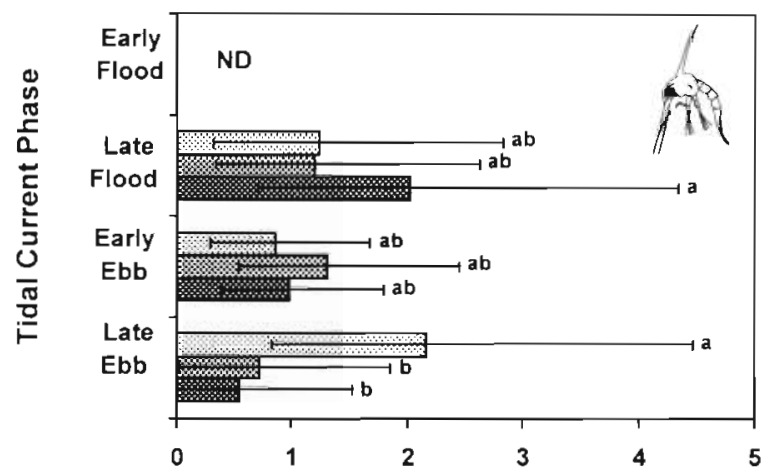

B. Day Samples

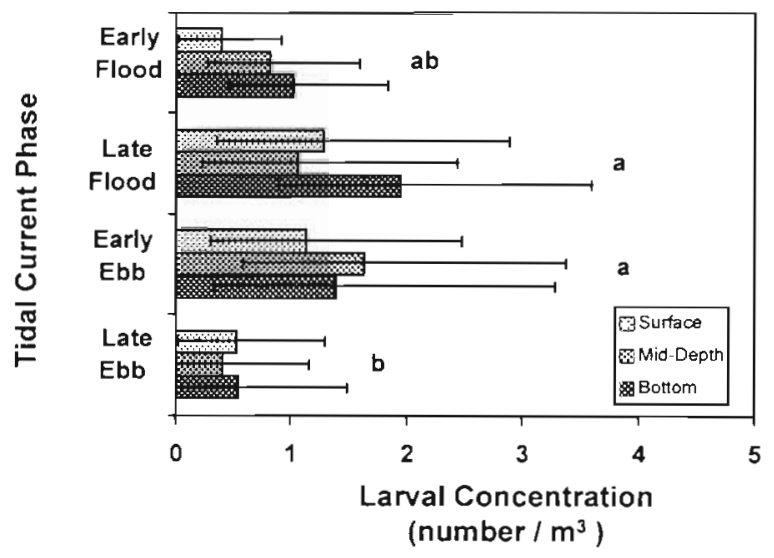

Fig. 6. Concentration of panopeid larvae by depth and tidal phase. Data presented as back-transformed mean larval concentration for each depth. Bars with different letters are significantly different (Student-Newman-Keuls multiple comparisons test). Error bars represent back-transformed 95\% confidence intervals. ND: no data

correlated with vertical position. Larvae were highest in the water column during ebb tides and during the later periods of the tidal phase. During early flood following low tide, larvae were near the bottom. During both late flood and early ebb (high tide), more larvae were near the surface. Larvae were highest in the water column during late ebb just prior to low tide (Fig. 9). Larvae rose in the water column during the period between successive low tides, then rapidly migrated downward between late ebb and early flood (Fig. 9).

\section{DISCUSSION}

The patterns of larval abundance observed in the present study reflect the combined influence of swimming behaviors and physical mixing. Larval vertical migration behaviors occurred in all 3 family groups. Uca spp. larvae were more abundant during the early 
Table 5. Logistic regression of depth distribution. Logistic regression models were fitted using a stepwise regression of explanatory variables (light. current, period, and date). Only significant factors were included in the final models. Overall model significance was tested using the $-2 \log$ Likelihood Chi-Squared, and adequate model fit was indicated by a non-significant Goodness of Fit test (Agresti 1989). All logistic models were highly significant and adequately fit the data

\begin{tabular}{|c|c|c|c|c|c|c|}
\hline Effect & $\mathrm{df}$ & Parameter estimate & SE & $z^{2}$ & $\mathrm{p}$ & Odds ratio \\
\hline \multicolumn{7}{|l|}{ UCa spp. } \\
\hline Intercept & 1 & -0.7878 & 0.2093 & 14.17 & 0.0002 & \multirow{3}{*}{1.981} \\
\hline Current & 1 & 0.6838 & 0.1594 & 18.41 & 0.0000 & \\
\hline Replicate & 1 & -0.0408 & 0.0714 & 0.33 & 0.5675 & \\
\hline \multicolumn{7}{|c|}{ Model significance: $\chi^{2}=18.74, \mathrm{df}=1, \mathrm{p}<0.001$} \\
\hline \multicolumn{7}{|c|}{ Pinnotheridae } \\
\hline Intercept & 1 & -0.7976 & 0.4263 & 3.50 & 0.0613 & \\
\hline Date & 1 & -0.2917 & 0.1245 & 5.49 & 0.0191 & 0.747 \\
\hline Current & 1 & 1.3682 & 0.3034 & 20.33 & 0.0000 & 3.928 \\
\hline Light & 1 & -0.5757 & 0.2417 & 5.67 & 0.0172 & 0.562 \\
\hline \multicolumn{7}{|c|}{ Model significance: $\chi^{2}=42.173, \mathrm{df}=3, \mathrm{p}<0.001$} \\
\hline \multicolumn{7}{|c|}{ Panopeidae } \\
\hline Intercept & 1 & -2.0775 & 0.3605 & 33.21 & 0.0000 & \\
\hline Current & 1. & 0.6248 & 0.1959 & 10.17 & 0.0014 & 1.868 \\
\hline Period & 1. & 0.7590 & 0.1949 & 15.16 & 0.0001 & 2.136 \\
\hline \multicolumn{7}{|c|}{ Model significance: $\chi^{2}=19.943, \mathrm{df}=2, \mathrm{p}<0.001$} \\
\hline
\end{tabular}

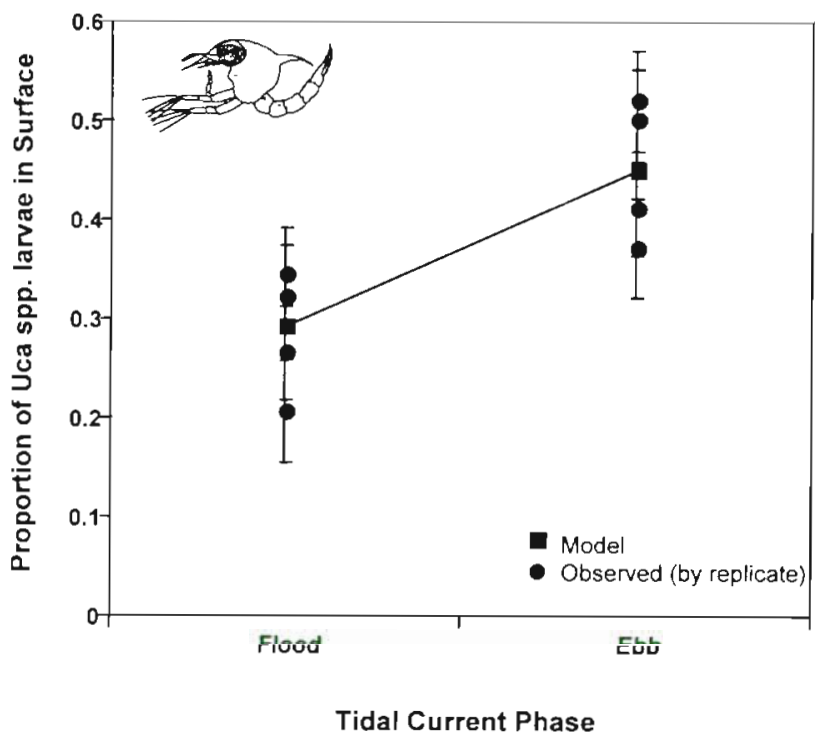

Fig. 7. Uca spp. Logistic regression model. Error bars show SE of observed value

portion of tidal current phases and were near the surface during ebb tides. In the Pinnotheridae, there were both light and tidally timed behaviors with larvae closer to the surface during night and ebbing tides. Panopeid zoeae were more abundant during late flood tides and early ebb tides, and larvae rose toward the surface between successive low tides. While these behaviors were indicated by the logistic regression, they were less apparent in the results of the ANOVA. The differences between the 2 tests reflect both the nature of the analyses and the processes underlying larval vertical distribution in estuarine habitats.

The logistic regression indicates clear and highly significant behaviors associated with light and tidal. currents. As a categorical analysis, logistic regression is largely insensitive to the variance in the data. Specifically, the model collapses across all replicates within a particular factor and tests the deviation of cell frequencies versus a chi-squared distribution (Agresti 1989). The logistic regression therefore ignores the variation between replicates. In contrast, the ANOVA is primarily sensitive to the variance that the logistic regression ignores. The weak significance in the ANOVA model reflects the high variability between replicates. The 2 tests together indicate both the behavioral and physical processes that are responsible for larval distribution and transport.

Tidal current velocities are generally highest near the surface and decline with depth. Vertically migrating larvae near the surface experience the strongest net transport during a particular tidal current phase (Hill 1995, Queiroga et al. 1997). This simple model is described as 'selective tidal stream transport' and occurs in a variety of species and taxa within estuarine systems (Boehlert \& Mundy 1988, Hill 1995, Queiroga et al. 1997).

The vertical migration behaviors of $U_{c a}$ spp. should promote rapid downstream transport. Behaviors timed solely to the tidal current phase appear to be strongly associated with larval dispersal strategies (Hill 1995). Similar behaviors occur in another exported species, Carcinus maenas (Zeng \& Naylor 1996b, Queiroga et 
A. 13-June

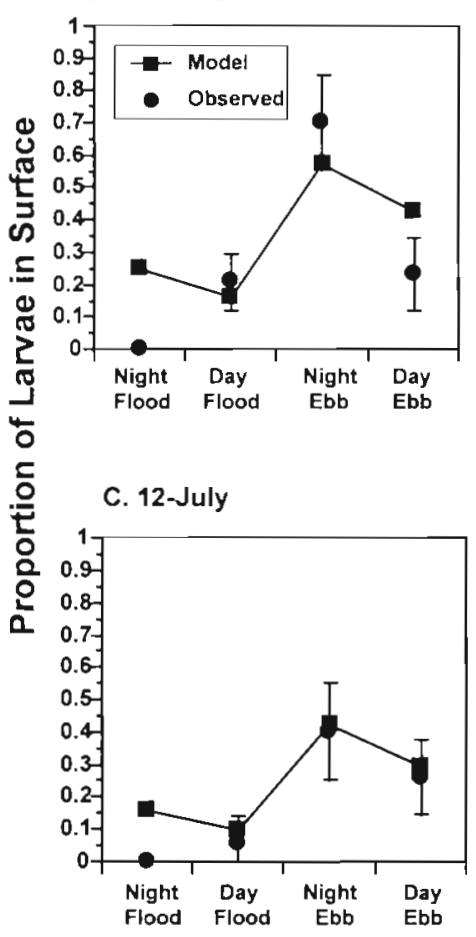

B. 27-June

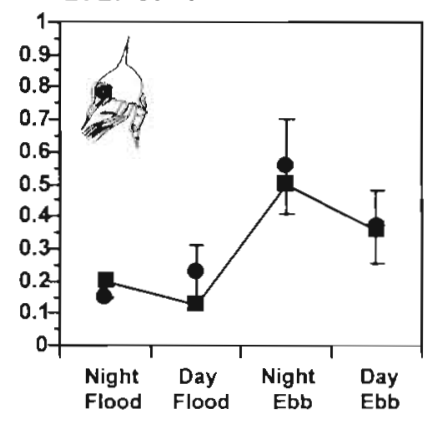

D. 27-July

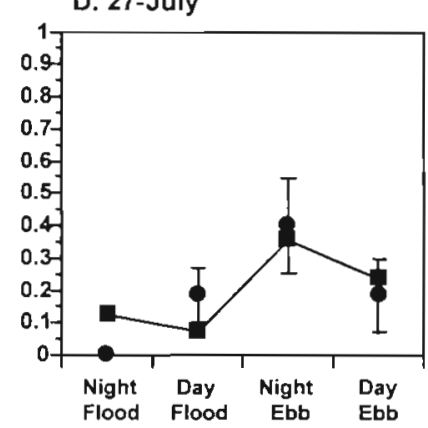

Fig. 8. Logistic regression model for Pinnotheridae. Error bars show $\mathrm{SE}$ of observed value

al. 1997). In contrast, the patterns in pinnotherid zoeae reflect behaviors correlated with both tidal and light stage. Light limited behaviors are typically considered a mechanism for predator avoidance and are indepen. dent of transport processes (Forward 1987. Hill 1991). Tidal stream transport is reduced during the day because larvae remain deeper in the water column The tidal behavior of the panopeid larvae does not appear to be directly tied to a particular dispersal strategy. Larvae are near the surface during late ebbing tides, which should result in downstream transport, but they experience reduced net transport during late floods and early ebbs. This behavior should promote very slow downstream dispersal.

These behavioral patterns are consistent with the horizontal distributions of larvae and post-larvae in these groups. UCa spp. zoeae are rapidly exported from upriver, shallow habitats to the mouths of estuaries and nearshore continental shelves (Johnson 1982, Epifanio et al. 1988). Pinnotherid post-larvae occur on the continental shelf (Johnson 1982), but the late zoeal stages are still abundant within the secondary estuaries, indicating slow downstream dispersal (Sandifer 1972). The panopeid zoeae are broadly distributed in the lower portions of estuarine systems (Sandifer 1972, Goy 1976), and they are retained within the estuary throughout development (Johnson 1982). While the observed behaviors are consistent with horizontal distributions, the extremely high variability in vertical distribution will have strong effects on the dispersal patterns and recruitment success of crab zoeae.

The small-scale variation observed in the present study is likely associated with strong vertical mixing typical of shallow estuarine habitats. Physical mixing can influence larval behaviors and directly alter vertical distribution. Assuming that larval responses to salinity and temperature in laboratory settings (e.g. Forward 1989) translate to the natural habitat, small changes in salinity or temperature associated with mixing may change larval behavior and reduce their ability to accurately regulate depth. In addition, strong vertical currents in fronts or tidal mixing may overcome larval swimming behaviors and prevent active depth regulation. The high flows in tidal inlets result in strong vertical mixing and reduce larval behavioral control over vertical position (Smith \& Stoner 1993). Strong wind events, freshwater input, and basin topography can all enhance vertical mixing and effect the distribution and transport of planktonic larvae.

This variability is further enhanced by the horizontal patchiness of larval distribution. The plankton samples in the present study were collected sequentially from a fixed location. Patches of larvae were sampled at random from the water mass moving past the study site within a short sampling period. Considerable horizontal variation in larval concentration is evident throughout the data. For example, in the noon sampling period on 12 July, 1 replicate sur-

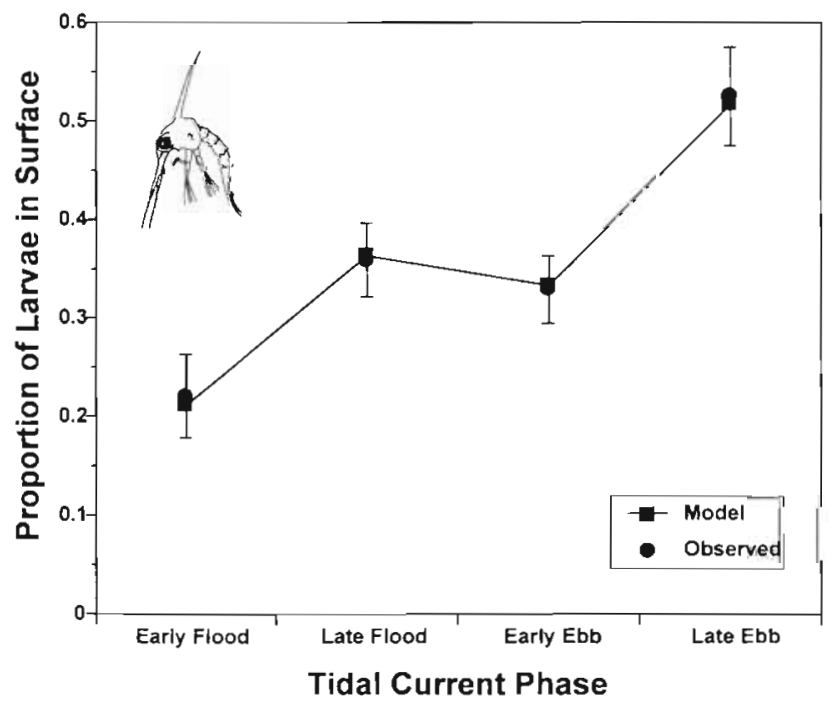

Fig. 9. Logistic regression model for Panopeidae. Error bars show SE of observed value 
face sample had very low $\left(<1 \mathrm{~m}^{-3}\right)$ densities of $U c a \mathrm{spp}$. larvae. The subsequent sample, collected approximately $10 \mathrm{~min}$ later, had extremely high densities of Uca spp. zoeae $\left(>500 \mathrm{~m}^{-3}\right)$. This type of patchiness is typical of planktonic systems (Rothschild \& Osborne 1988). Turbulent processes and frontal systems that concentrate and entrain larvae, their predators, and their prey can potentially have a strong influence on larval recruitment success (Clancy \& Epifanio 1988, Rothschild \& Osborne 1988). In addition to potential enhancement of contact rates with predators (e.g. Rothschild \& Osborne 1988), these processes may also strongly influence the advective transport of larvae.

Previous studies of the transport of vertically migrating larvae in estuarine systems have typically focused on fairly simple models of physical and behavioral processes. Field studies of larval behavior have been either conducted over large spatial and temporal scales (e.g. Sandifer 1972, Dittel \& Epifanio 1982) or replicated over several consecutive tidal cycles (e.g. Cronin \& Forward 1982, Brookins \& Epifanio 1985, Epifanio et al. 1988, Queiroga et al. 1997). These sampling periods filter out high frequency 'noise' and reveal the behavioral processes underlying larval vertical distribution patterns. The replication in the present study occurred on the scale of minutes and captured the influence of small-scale mixing associated with turbulence. When the variance between replicates is filtered out in the logistic regression, larval behavioral patterns are clearly defined. However, when this variability is included in the ANOVA model, the behavioral patterns are much less apparent. This small-scale variation has generally been ignored in the treatment of larval transport in estuarine systems, and its influence on larval transport and recruitment success are unclear. Future studies should examine the influence of turbulent processes on the variability in distribution and recruitment success in planktonic larvae.

Acknowledgements. The author gratefully acknowledges the assistance of J. Morgan and K. Garrison in the collection and analysis of plankton samples. R. Lipcius, F. Chu, R. Mann, J. van Montfrans, A. Hines, K. Garrison and 3 anonymous reviewers provided valuable reviews of early versions of the manuscript. Funding for equipment and supplies was provided by the NOAA Office of Sea Grant, U.S. Department of Commerce, Grant no. NA-90AA-D-SG-45 to the Virginia Graduate Marine Science Consortium and Virginia Sea Grant College Program. Financial support for the author was generously provided by the Willard A. Van Engel Foundation. VIMS Contribution No. 2189.

\section{LITERATURE CITED}

Agresti A. (1989) Categorical data analysis. John Wiley and Sons, Inc, New York
Boehlert GW, Mundy BC (1988) Roles of behavioral and physical factors in larval and juvenile fish recruitment to estuarine nursery areas. Amer Fish Soc Symp 3:51-67

Brookins KG, Epifanio CE (1985) Abundance of brachyuran larvae in a small coastal inlet over six consecutive tidal cycles. Estuaries 8:60-67

Clancy M, Epifanio CE (1988) Distribution of crab larvae in relation to tidal fronts in Delaware Bay, USA. Mar Ecol Prog Ser 57:77-82

Cronin TW, Forward RB Jr (1982) Tidally timed behavior: effects on larval distributions in estuaries. In: Kennedy VS (ed) Estuarine comparisons. Academic Press, New York, p 505-520

Cronin TW, Forward RB Jr (1986) Vertical migration cycles of crab larvae and their role in larval dispersal. Bull Mar Sci 39(2): 192-201.

Dittel AI, Epifanio CE (1982) Seasonal abundance and vertical distribution of crab larvae in Delaware Bay. Estuaries 5:197-202

Epifanio CE (1984) Dispersal and recruitment of blue crab larvae in Delaware Bay, USA. Estuar Coast Shelf Sci 18:1-12

Epifanio CE (1988a) Transport of crab larvae between estuaries and the continental shelf. In: Jansson BO (ed) Coastaloffshore ecosystem interactions. Lecture notes on coastal and estuarine studies, Vol 22. Springer-Verlag, Berlin, p 291-305

Epifanio CE (1988b) Transport of invertebrate larvae between estuaries and the continental shelf. Am Fish Soc Symp 3: $104-114$

Epifanio CE, Little KT, Rowe PM (1988) Dispersal and recruitment of fiddler crab larvae in the Delaware River estuary. Mar Ecol Prog Ser 43:181-188

Forward RB Jr (1987) Comparative study of crustacean larval photoresponses. Mar Biol 94:589-595

Forward RB Jr (1989) Depth regulation of larval marine decapod crustaceans: test of an hypothesis. Mar Biol 102: 195-201

Goy JA (1976) Seasonal distribution and the retention of some decapod crustacean larvae within the Chesapeake Bay, Virginia. MSc thesis, Old Dominion University, Norfolk VA

Hill AE (1991) Vertical migration in tidal currents. Mar Ecol Prog Ser 75:39-54

Hill AE (1995) The kinematical principles governing horizontal transport induced by vertical migration in tidal flows. J Mar Biol Assoc UK 75:3-13

Hines AH (1986) Larval patterns in the life histories of brachyuran crabs (Crustacea, Decapoda, Brachyura). Bull Mar Sci 39(2):444-466

Hosmer DW, Lemeshow S (1989) Applied logistic regression. John Wiley and Sons, Inc, New York

Huzzey LM (1986) Lateral variability in a coastal plain estuary. PhD dissertation, College of William and Mary. Gloucester Point, VA

Johnson DF (1982) A comparison of recruitment strategies among brachyuran crustacean megalopae of the York River, lower Chesapeake Bay and adjacent shelf waters PhD dissertation, Old Dominion University, Norfolk, VA

Martin JW, Abele LG (1986) Notes on male pleopod morphology in the brachyuran crab family Panopeidae Ortmann, 1893, sensu Guinot (1978) (Decapoda). Crustaceana 50(2): $182-198$

McConaugha JR (1988) Export and reinvasion of larvae as regulators of estuarine decapod populations. Am Fish Soc Symp 3:90-103

Milliken GA, Johnson DE (1984) Analysis of messy data. Vol 1: Designed experiments. Van Nostrand Reinhold Company, New York 
Morgan SG (1986) The impact of planktivory on the life histories of estuarine crabs. PhD dissertation, University of Maryland, Cambridge

Morgan SG, Christy JH (1995) Adaptive significance of the timing of larval release by crabs. Am Nat 145:457-479

Newman JA, Bergelson J, Grafen A (1997) Blocking factors and hypothesis tests in ecology: is your statistics text wrong? Ecology 78:1312-1320

Olmi EJ (1994) Vertical migration of blue crab Callinectes sapidus megalopae: implications for transport in estuaries. Mar Ecol Prog Ser 113:39-54

Queiroga H, Costlow JD, Moreira MH (1997) Vertical migration of the crab Carcinus maenas first zoeae in an estuary implications for tidal stream transport. Mar Ecol Prog Ser 149:121-132

Rothschild BJ, Osborne TR (1988) Small-scale turbulence and plankton contact rates. J Plankton Res 10:465-473

Sandifer PA (1972) Morphology and ecology of Chesapeake Bay decapod crustacean larvae. PhD dissertation, University of Virginia, Charlottesville

Smith NP, Stoner AW (1993) Computer simulation of larval transport through tidal channels: role of vertical migration. Estuar Coast Shelf Sci 37:43-58

Editorial responsibility: Kenneth Heck (Contributing Editor), Dauphin Island, Alabama, USA
Sokal R, Rohlf FJ \{1981) Biometry. The principles and practice of statistics in biological research. WH Freeman and Company, New York

Sulkin SD (1984) Behavioral basis of depth regulation in the larvae of brachyuran crabs. Mar Ecol Prog Ser 15:181-205

Underwood A.J (1981) Techniques of analysis of variance in experimental marine biology and ecology. Oceanogr Mar Biol Annu Rev 19:513-605

Williams AB (1984) Shrimps, lobsters, and crabs of the Atlantic coast of the eastern United States, Maine to Florida. Smithsonian Institution Press, Washington, DC

Young CM (1995) Behavior and locomotion during the dispersal phase of larval life. In: McEdward L (ed) Ecology of marine invertebrate larvae. CRC Press, Boca Raton, p 249-278

Zeng C, Naylor E (1996a) Endogenous tidal rhythms of vertical migration in field collected zoeae- 1 larvae of the shore crab Carcinus maenas: implications for ebb tide off-shore dispersal. Mar Ecol Prog Ser 132:71-82

Zeng C, Naylor E (1996b) Synchronization of endogenous tidal vertical migration rhythms in laboratory-hatched larvae of the crab Carcinus maenas. J Exp Mar Biol Ecol 198 . 269-289

Submitted: April 10, 1997; Accepted: September 10, 1998 Proofs received from author(s): December 22, 1998 